Revolt of the Saints 



\section{Revolt of the Saints}

Memory and Redemption in the Twilight of Brazilian Racial Democracy

JOHNF. COLLINS

Duke University Press $\quad$ Durham and London 2015 
(C) 2015 Duke University Press

All rights reserved

Printed in the United States of America on acid-free paper

Designed and typeset by Julie Allred, BW\&A Books, Inc.

Library of Congress Cataloging-in-Publication Data

Collins, John F., 1965 April 19-

Revolt of the saints : memory and redemption in the twilight

of Brazilian racial democracy / John F. Collins.

pages $\mathrm{cm}$

Includes bibliographical references and index.

ISBN 978-0-8223-5306-5 (hardcover : alk. paper)

ISBN 978-o-8223-9570-6 (e-book)

ISBN 978-o-8223-5320-1 (pbk. : alk. paper)

1. Pelourinho (Salvador, Brazil)—Social conditions.

2. Pelourinho (Salvador, Brazil)

-Race relations. 3. Blacks-Brazil-Salvador. I. Title.

F2651.S136P4535 2015

$981^{\prime} .42-\mathrm{dc} 23$

2015008870

Cover photo by John Collins

Duke University Press gratefully acknowledges the support of Queens College, City University of New York, and the Queens College Foundation, which provided funds toward the publication of this book. 
To F. W. Manasek 
